\title{
Bioactive compounds of ethanol extract from agarwood leaves (Aquilaria malaccensis) and antimicrobial activity against bacteria and fungi growing on the skin
}

\author{
RIDWANTI BATUBARA ${ }^{1, \bullet}$, BASUKI WIRJOSENTONO ${ }^{1, \vee v}$, AMIR HAMZAH SIREGAR ${ }^{1}$, URIP HARAHAP ${ }^{2}$ \\ TAMRIN ${ }^{1}$ \\ ${ }^{1}$ Department of Chemistry, Faculty of Mathematics and Natural Sciences, Universitas Sumatera Utara, Jl. Bioteknologi No. 1, USU Campus, Medan \\ 20155, North Sumatra, Indonesia. Tel.: +62-61-8214290, ”email: ridwantibb@yahoo.com, •vbasuki@usu.ac.id \\ ${ }^{2}$ Faculty of Pharmacy, Universitas Sumatera Utara. Jl. Tridharma No. 5, USU Campus, Medan 20155, North Sumatra, Indonesia
}

Manuscript received: 15 January 2021. Revision accepted: 27 April 2021.

\begin{abstract}
Batubara R, Wirjosentono B, Siregar AH, Harahap U, Tamrin. 2021. Bioactive compounds of ethanol extract from agarwood leaves (Aquilaria malaccensis) and antimicrobial activity against bacteria and fungi growing on the skin. Biodiversitas 22: $2884-2890$. Agarwood plants (Aquilaria malaccensis Lamk.) provide numerous benefits and have been cultivated by the people. The leaves containing various compounds, such as flavonoids, glycosides, triterpenoids and tannins with antibacterial and antifungal activities, were reported to be potential for flesh wound healing. Therefore, research on these activities against microorganisms that cause infection in wounds was carried out in vitro. This research aims to determine the antibacterial and antifungal activities of agarwood leaves ethanol extract against three bacteria species (Staphylococcus epidermidis, Staphylococcus aureus, and Propionibacterium acnes) and two fungi species (Candida albicans and Trichophyton sp.) that commonly cause skin infection. The results of this research show that the concentration of ethanol extract of agarwood leaves affected the bacterial and fungal growth inhibition zone's diameter. The best inhibitory potential occurred at 5\% concentration in activity against bacteria and fungi. The extract's active compounds contributing to the antimicrobial activity were the flavonoids and tannins. Furthermore, GC-MS identification shows that the ethanol extract from agarwood leaves contained Disulfide, dioctyl; 6,7-Dimethylquinoxaline; (E)-1,3-Di-m-tolylallyl ethyl Carbonate; 5-(2-Methoxyphenyl)1,2-dihydropyrazol-3-one; 9-[(tert-Butyldimethylsilyl)oxy]benzo[3,4]cyclod ec-3-ene-1,5-diyne; Neophytadiene, 2-Hexadecen-1-ol, 3,7,11,15-tetramethyl-, [R-[R*, $\mathrm{R}^{*}$-(E)]]-; Hexadecanoic acid, methyl ester and a-(3-chloro-4-hydroxyphenyl)-aphenoxy-a-phenyl acetonitrile.
\end{abstract}

Keywords: Agarwood leaves, bacteria, fungi, inhibition zone's diameter, skin

\section{INTRODUCTION}

Several studies have reported the benefits of Aquilaria leaves for humans. The leaves contain various chemical constituents including 2- (2-phenylethyl) chromones, phenolic acids, steroids, fatty acids, benzophenones, xanthonoids, flavonoids, terpenoids, and alkanes. They are assumed to be associated with beneficial pharmacological properties, including analgesic, anti-rheumatic, antiinflammatory, anticancer, antitumor, antioxidant, antibacterial, antifungal, antidiabetic, antihistamine, lipidlowering, laxative, acetylcholinesterase (pain) inhibition, and hepatoprotective (Adam et al. 2017). It indicates the potentials of agarwood leaves as a source of medicine.

Previous studies have explained the antimicrobial properties of agarwood leaves. The Minimum Inhibitory Concentration (MIC) of leaves extract in inhibiting the growth of Staphylococcus aureus ATCC 25923 was 2.5 $\mathrm{mg} / \mathrm{mL}$ with an inhibitory diameter of $7.00 \pm 0.00 \mathrm{~mm}$ (Liana 2017). Agarwood leaves extract with a concentration of $30 \%$ showed the best antibacterial activity with an inhibition zone area of $9.65 \mathrm{~mm}$ against Pseudomonas aeruginosa and $13.50 \mathrm{~mm}$ against $S$. aureus (Jansen 2017). The ethanol extract from agarwood leaves with the concentration of $300 \mathrm{mg} / \mathrm{mL}, 400 \mathrm{mg} / \mathrm{mL}$, and 500 $\mathrm{mg} / \mathrm{mL}$ inhibited S. aureus with the average of inhibition zone diameter of $12.50 \mathrm{~mm}, 13.51 \mathrm{~mm}$, and $15.80 \mathrm{~mm}$, respectively, and also inhibited Proteus mirabilis with the average yield of inhibition zone diameter of $10.17 \mathrm{~mm}$, $11.62 \mathrm{~mm}$, and $13.41 \mathrm{~mm}$, respectively (Sari et al. 2017). The most excellent performance of the extract in inhibiting S. aureus bacteria was at the concentration of $450 \mathrm{mg} / \mathrm{mL}$ with an average inhibition zone diameter of $21.17 \pm 3.32$ $\mathrm{mm}$ (Wahid and Ittiqo 2019).

The development of natural ingredients for wound medicine derived from plants requires further research. The utilization of these raw materials is due to its renewable and relatively small negative impact. Thus, it is necessary to experiment with producing wound medicine ingredients from agarwood leaves extract. During the healing process, the wound is sometimes followed by infection from both fungal and bacterial groups. Therefore, this research's initial step is assessing the antimicrobial properties of agarwood leaves against bacteria and fungi that grow on the skin and commonly cause flesh wound infection. The three bacteria species are Staphylococcus epidermidis, Staphylococcus aureus, and Propionibacterium acnes, and the two fungi species are Candida albicans and Trichophyton sp. 
Infectious disease becomes one of the health problems in society that is difficult to overcome completely (Qomar 2018). Infectious diseases, which are easily transmitted, can be caused by bacteria, fungi, viruses, and parasites (Diyantika et al. 2017). One of the bacteria S. epidermidis that can be generally responsible for swelling in skin infections is abscesses or acne (Radji 2011). Another bacteria is $S$. aureus which plays an essential role in infection of the hair follicles and sweat glands, acne, abscesses, impetigo, and wounds infection. This bacterium has low invasion ability but is involved in many skin infections (Miller et al. 2012). It is commonly found around the human environment as the cause of most skin infections due to its ability to adapt and its resistance to antimicrobial properties. Although, it is also found on mucous membranes and can cause sore throat and infections of the central nervous system and lungs (Diyantika et al. 2017). Some infection cases caused by $S$. aureus are acne, impetigo, and wound infection (Mardiah 2018).

Propionibacterium acnes is an anaerobic gram-positive bacterium that causes inflammation on the skin (Brzuszkiewicz et al. 2011). This bacterium is the primary organism that plays a role in the formation of acne (Aida et al. 2016). C. albicans is the most often isolated species in humans (Listiyawati et al. 2017). It usually causes candidiasis, an acute and subacute fungal disease affecting the skin of the mouth, vagina, nails, skin, bronchi, or lungs (Farizal 2017).

Three main genera of dermatophyte fungi responsible for the fungal disease of the skin are Epidhermophyton, Microsporum, and Trichophyton (Tambayong 2000). Trichophyton is fungi that often affect hair, skin, and nails (Sintowati et al. 2008).

This research aims to determine the bioactive compounds of ethanol extract from agarwood leaves (Aquilaria malaccensis). In addition, this research aims to determine the antibacterial and antifungal activities of agarwood leaves ethanol extract against bacteria and fungi species that commonly cause skin infection.

\section{MATERIALS AND METHODS}

\section{Time and place of research}

This research was conducted from August 2019 to March 2020. The sampling was located at Pekan Bahorok Village, Bahorok Subdistrict, Langkat District, North Sumatra Province, Indonesia. Phytochemical analyses were carried out at the Phytochemical Laboratory, Faculty of Pharmacy, University of Sumatera Utara (USU), Medan, Indonesia. Antimicrobial activity analyses were carried out at the Microbiology Laboratory, Faculty of Pharmacy, USU. The characterization and extraction were carried out at the Forest Products Technology Laboratory, Faculty of Forestry, USU. Whereas. the GC-MS analysis was conducted at Customs and Excise (Bea Cukai) Laboratory of North Sumatra, Medan.

\section{Agarwood leaves sampling}

The sample used in this study was Aquilaria malaccensis species., cultivated by the local people in the Bahorok Subdistrict, Langkat District, North Sumatra, Indonesia. This species is identified and deposited in Medanense Herbarium.

\section{Raw material preparation}

At this step, the agarwood leaves were cleaned by rinsing with running water, spread on parchment paper until the water was absorbed. Afterward, the samples were dried using a drying cabinet with a temperature of $40^{\circ} \mathrm{C}-$ $50^{\circ} \mathrm{C}$ until dry and brittle. Dried leaves were then blended using a blender into powder and stored in the polyethylene plastic and in a place protected from the sun before being extracted and analyzed.

\section{Ethanol extraction of the agarwood leaves powder}

The extract was obtained using the maceration method with $96 \%$ ethanol solvent. As much as $200 \mathrm{~g}$ of simplicia powder was put into a glass container, poured with 1500 $\mathrm{mL}$ of the ethanol, covered, kept protected from light aside, and occasionally stirred. After five days, the mixture was filtered. Then the powder was soaked again with a $96 \%$ ethanol solution of $1500 \mathrm{~mL}$, left in a place protected from light for 2 more days. After 2 days, the mixture was then filtered again. The first and second filter (macerate) results were then combined. The residue was then soaked with $96 \%$ ethanol sufficiently to obtain $2000 \mathrm{~mL}$ of the mixture, transferred into a closed vessel, and left in a cool place protected from light for two days, then filtered. All collected filtrates were concentrated using a rotary evaporator at $40^{\circ} \mathrm{C}$ until a thick liquid was obtained and then dried using a freeze dryer to get a dry extract (Batubara et al. 2020).

\section{Phytochemical screening and tannin content determination}

The chemicals used for testing are pro-analysis quality chemicals, produced by E-Merck, Germany. Phytochemical tests include examining flavonoids, alkaloids, saponins, tannins and steroids/triterpenoids, referring to Harborne (1987) and MoHRI (2000). Testing of tannin levels was carried out using the Lowenthal-Procter method (Sudarmadji et al. 1984): (i) A total of $5 \mathrm{~g}$ of finely ground material was added to $400 \mathrm{~mL}$ of distilled water and then boiled for 30 minutes. (ii) It was then cooled, filtered, and put into a $500 \mathrm{~mL}$ measuring flask and added with distilled water until the specified mark (phytate 1). (iii) $10 \mathrm{~mL}$ of phytate I was taken and added with $25 \mathrm{~mL}$ of indigo carmine solution and $750 \mathrm{~mL}$ of distilled water. Then it was titrated with $0.1 \mathrm{~N} \mathrm{KMnO}_{4}$ solution until it turned to a golden yellow color. (iv) $100 \mathrm{~mL}$ of phytate I was taken and added with $50 \mathrm{~mL}$ of gelatin solution, $100 \mathrm{~mL}$ of acid salt solution, and $10 \mathrm{~g}$ of kaolin powder, respectively. Furthermore, it was shaken vigorously for a few minutes and filtered (filtrate II). (v) $25 \mathrm{~mL}$ of phytate II was taken and mixed with $25 \mathrm{~mL}$ of indigo carmine solution and 750 $\mathrm{mL}$ of distilled water. Then, it was titrated with $0.1 \mathrm{~N}$ $\mathrm{KMnO}_{4}$ solution. (vi) Standardization of $\mathrm{KMnO} 4$ solution is Na-oxalate. 
Calculation:

$$
\text { Tannin Level }=\frac{(50 \mathrm{~A}-50 \mathrm{~B}) \times 0.1 \times 0.00416}{\text { Sample Weight }} \times 100 \%
$$

Where:

$$
\begin{aligned}
& \mathrm{A}: \text { Tannin titration volume }(\mathrm{mL}) \\
& \mathrm{B}: \text { Volume of blank titration }(\mathrm{mL}) \\
& \mathrm{N}: \text { Normality standard } \mathrm{KMnO} 4(\mathrm{~N}) \\
& 10: \text { Dilution factor, } 1 \mathrm{~mL} \text { of } \mathrm{KMnO} 40.1 \\
& \mathrm{~N}: \text { : equivalent with } 0.00416 \mathrm{~g} \text { of tannin }
\end{aligned}
$$

\section{Antimicrobial activity (against bacteria and fungi commonly growing on the skin)}

Preparation and evaluation of antibacterial activity using the disc diffusion method (Kirby-Bauer Test)

Preparation steps include bacterial rejuvenation, making bacterial suspensions, making paper discs, preparing negative controls, preparing positive controls, and making series of concentrations. This research is a series of research for applications, so that it takes into account the safety aspect. The initial concentration refers to Surjanto et al. (2019), wherein this research the initial concentration was $1.30 \%$. However, for ease of production and calculation, the initial concentration was reduced to $1.25 \%$. The subsequent concentrations were multiples of $2.5 \%$, $5 \%, 10 \%$ and $20 \%$. Antibacterial activity evaluation used the disc method (Peng and Zhao 2009). The disc method was carried out using $6 \mathrm{~mm}$ diameter paper discs and agar media that had been sterilized as bacterial growth media.

The evaluation used three species of bacteria, namely: Staphylococcus epidermidis ATCC 12228, Staphylococcus aureus ATCC 25923, and Propionibacterium acnes ATCC 6919. Bacteria were inoculated in Petri dishes which had been filled with agar media. Afterward, the disc paper was dipped in the ethanol extract from agarwood leaves and then placed on agar media. After being incubated for 48 hours, the inhibition zone (area that was not loaded by bacteria) diameter was measured using calipers. The test was carried out with three replications. The positive control was prepared using amoxicillin, while the negative control was prepared using ketoconazole.

Fungal incubation and assessment of agarwood leaves extract

The assessment of antifungal activity refers to Al-Enazi (2018), where the fungi were grown on Müeller-Hinton and Nutrient agar media on Petri dishes. Furthermore, the disc was added to the ethanol extract of agarwood leaves according to the treatment's concentration. Incubation was carried out at $35^{\circ} \mathrm{C}$ for $72-120$ hours. The extract's effectiveness an antifungal was measured by observing the clear zone formed around the diffusion discs and Whatman paper. Candida albicans ATCC 10231 and Trichophyton sp. ATCC 18748 were used in this study.

\section{The GC-MS analysis}

Identification of compounds from agarwood leaves ethanol extract was carried out using Gas ChromatographyMass Spectrometry (GC-MS). The instrument is GC-MS 7890B.

\section{RESULTS AND DISCUSSION}

\begin{tabular}{|c|c|c|c|}
\hline $\begin{array}{l}\text { Compound } \\
\text { groups }\end{array}$ & Reagents & Positively results (reference) & The result of the extract \\
\hline Flavonoids & $\begin{array}{l}\mathrm{Mg} \text { powder }+\mathrm{HCl} \\
\text { concentrated }+ \text { amyl alcohol }\end{array}$ & $\begin{array}{l}\text { Colored solution (red, yellow, orange) } \\
\text { on the amyl alcohol layer (MoHRI 2000) }\end{array}$ & $\begin{array}{l}(+) \\
\text { Red color on the amyl alcohol layer }\end{array}$ \\
\hline Alkaloids & $\begin{array}{l}\mathrm{HCl}+\text { Dragendorff/ Meyer } \\
\text { reagents + Bouchardat } \\
\text { reagents }\end{array}$ & Red/white precipitate (MoHRI 2000) & $\begin{array}{l}(-) \\
\text { Neither white nor yellow precipitate was } \\
\text { presented on the Meyer; neither brown nor } \\
\text { brownish-orange on the Dragendrorff and } \\
\text { neither brown nor dark brown on the } \\
\text { Bouchardat reagents }\end{array}$ \\
\hline Saponins & Shaked $+\mathrm{HCl} 2 \mathrm{~N}$ & Stable foam (MoHRI 2000) & $\begin{array}{l}(-) \\
\text { The formed foam was unstable and } \\
\text { diminished after the addition of } \mathrm{HCl} 2 \mathrm{~N}\end{array}$ \\
\hline Tannins & $+\mathrm{FeCl}_{3} 1 \%$ & $\begin{array}{l}\text { Blue or dark green color was formed } \\
\text { (MoHRI 2000) }\end{array}$ & $\begin{array}{l}(+) \\
\text { The solution became dark blue after the } \\
\text { addition of the } \mathrm{FeCl}_{3} 1 \%\end{array}$ \\
\hline $\begin{array}{l}\text { Steroids/ } \\
\text { triterpenoids }\end{array}$ & $\begin{array}{l}\text { + Lieberman-Burchard } \\
\text { reagents }\end{array}$ & $\begin{array}{l}\text { The blue or greenish-blue color indicated } \\
\text { the presence of steroids, while red, pink, } \\
\text { or purple color indicated the presence of } \\
\text { triterpenoids (Harborne 1987). }\end{array}$ & $\begin{array}{l}(+) \\
\text { The solution became purplish-red after the } \\
\text { addition of concentrated sulfuric acid } \\
\text { solution }\end{array}$ \\
\hline
\end{tabular}

\section{Phytochemical screening and tannin content}

Phytochemical screening results of agarwood leaves ethanol extract are presented in Table 1, which are presented in detail test results based on the reference literature.

Table 1. Phytochemical screening results of the agarwood leaves ethanol extract

Notes: +: positively contain the compounds, -: negatively contain the compounds 
Table 2. Inhibitory zone diameters $(\mathrm{mm})$ of the ethanol extract from agarwood leaves against the tested bacteria Staphylococcus epidermidis, Staphylococcus aureus, and Propionibacterium acnes

\begin{tabular}{llll}
\hline \multicolumn{1}{c}{$\begin{array}{c}\text { Concentrations } \\
\text { and controls (\%) }\end{array}$} & \multicolumn{3}{c}{ Sested bacteria } \\
\hline 20.00 & $10.43 \pm 0.76$ & $9.23 \pm 0.97$ & $11.47 \pm 0.59$ \\
10.00 & $9.90 \pm 0.43$ & $8.33 \pm 1.50$ & $10.73 \pm 0.98$ \\
5.00 & $8.23 \pm 0.11$ & $19.90 \pm 2.08$ & $7.93 \pm 0.32$ \\
2.50 & $7.80 \pm 0.10$ & $16.40 \pm 3.11$ & $7.26 \pm 0.38$ \\
1.25 & $7.40 \pm 0.20$ & $12.7 \pm 3.42$ & $6.90 \pm 0.17$ \\
$\begin{array}{l}\text { Positive control } \\
\text { (Amoxicillin) }\end{array}$ & $12.73 \pm 2.45$ & $12.73 \pm 2.45$ & $12.73 \pm 2.45$ \\
$\begin{array}{l}\text { Negative control } \\
\text { (Ketoconazole) }\end{array}$ & $0.00 \pm 0.00$ & $0.00 \pm 0.00$ & $0.00 \pm 0.00$ \\
\hline
\end{tabular}

The agarwood leaves extract positively contained flavonoids, tannin, and steroids/triterpenoids compounds. Meanwhile, the leaves extract did not contain saponins because it produced an unstable foam with a thickness of 1 $\mathrm{cm}$ which was diminished after the addition of $\mathrm{HCl} 2 \mathrm{~N}$. The leaves extract did not contain alkaloids either. None of the three reagents tested showed positive results.

Phytochemical screening provided important information about the chemical compounds of agarwood leaves. Screening techniques assisted phytopharmacological steps in the initial selection of the plant analysis to prove the presence of certain chemical compounds and, furthermore, be associated with the biological activity (Farnsworth 1996).

Ethanol extract from agarwood leaves positively contained tannin compounds. The quantitative analyses show that the extract contained $4.64 \pm 0.49 \%$ of tannin. This tannin content was not much different from the results of the research on agarwood tannin levels of type $W$. tenuiramis of $4.95 \%$ and A. malaccensis of $5.62 \%$ (Batubara et al. 2018).

\section{Evaluation of antimicrobial activity \\ Antibacterial activity}

The maximum inhibitory zones of the agarwood leave ethanol extract against three bacteria species are shown in Table 2. The highest result of $S$. epidermis and P. acnes was on $20 \%$ concentration whereas S. aureus was on $5 \%$ concentration.

Statistical analysis shows that extract concentrations affected the inhibitory zone against tested fungi. There was no significant difference between $5.00 \%$ concentration and control. The concentrations of $1.25 \%, 2.50 \%, 10.00 \%$ and $20.00 \%$ were insignificant difference either. According to Clinical Laboratory Standard Institute (CLSI) (2013), inhibit zone classified as resistant (inhibitory zone diameters $\leq 14 \mathrm{~mm}$ ), intermediate (inhibitory zone diameters $15-18 \mathrm{~mm}$ ) and susceptible (inhibitory zone diameters $\geq 19 \mathrm{~mm}$ ). Based on inhibitory these, the inhibitory zone classifications of $S$. aureus were classified as susceptible (at $5.00 \%$ concentration) and intermediate (at $2.5 \%$ concentration). In the same way, the rest concentration treatment for all bacteria were classified as resistant.

The prior experiments by Khasanah et al. (2014) showed that the higher a concentration, the higher the active components in it, so the inhibitory zones differed for each concentration. However, the increasing concentration sometimes stops effecting antibacterial activity at a particular level. It can be seen that 5.005 was the optimum concentration for $S$. aureus. Antimicrobial substances are capable of inhibiting or killing living microorganisms (Gobel et al. 2008).

Agarwood leaves are beneficial to health. They can be utilized as sources of antimicrobial substances, since the phytochemical screening result shows that they contained flavonoids, tannins, and steroids/triterpenoids. This is in line with Pelczar and Chan (2008) who stated that antimicrobial substances with bacterial growth and metabolism. can control microorganisms, prevent spoilage, and damage by microorganisms.

Phytochemical screening results show that the extract contained flavonoids and tannins. Flavonoids are active as antibacterials by forming complex compounds with extracellular and dissolved proteins that damaging bacterial cell membranes by the release of intracellular compounds. Flavonoids play a role in inhibiting DNA-RNA synthesis by bonding intercalation or hydrogen with the buildup of nucleic acid. Besides, they also hamper the energy metabolism in a similar way to inhibition of the respiratory system because it requires sufficient energy for the active absorption of various metabolites and macromolecules' biosynthesis. Phenol compound is capable of breaking the peptidoglycan bonds when they go through the cell wall. Peptidoglycan is an essential layer for the survival of bacteria in a hypotonic environment. The breakage of layer results in the stiffening of the bacterial cell and subsequently the death of the bacteria (Dewi 2010). The previous study by Kahraman et al. (2019) found that the three flavonoids obtained from ethyl acetate extract of Ferula caspica had the highest antimicrobial and antioxidant activity.

Tannins also contribute to antibacterial activity due to their chemical property which is similar to mild acids because of the phenolic OH-groups (Ismarani 2012). Tannic acid is the simplest form of hydrolyzable tannin. Although tannin acid can function as a natural antimicrobial agent, it is not active against a broad spectrum of fungi and bacteria. Higazy et al. (2010) revealed that the burlap fabric treated to form a metal tannic acid-complex showed an increase in antimicrobial activity compared to samples treated with tannic acid only or metal ions only at the same concentration.

The positive control used amoxicillin, a penicillinderived antibiotic that has a broad spectrum of action, with a mechanism of inhibiting bacterial cell wall synthesis. The use of positive control aimed to see a picture of tested bacteria death seen from the inhibition zone. The negative control treatment was ketoconazole with an average inhibition zone diameter of $0.00 \mathrm{~mm}$ (no clear area around the disc). 


\section{Antifungal activity}

The maximum inhibitory zone of the ethanol extract from agarwood leaves against two fungi species can be seen in Table 3. It shows that the higher concentration of extracted substances, the higher the average inhibition zone diameter. The inhibitory zone diameters against $C$. albicans were higher than against Trichophyton $\mathrm{sp}$.

The highest concentration shows the best result in inhibiting the growth of $C$. albanicans and Trichophyton sp. The concentration treatments have statistically affected the fungi inhibitory zone. There was no significant difference between the $5.00 \%$ and $20.00 \%$ statistic test result concentration treatment and effect on inhibitory zone against fungi. Statistical analysis shows that treatments used $5.00 \%$ and $20.00 \%$ concentrations and between $2.50 \%$ and $10.00 \%$ concentrations. Based on CLSI classification, the inhibitory zone of $C$. albicans was classified intermediate (at $20.00 \%$ concentrations) and the rest concentration was classified as resistant. The inhibitory zone of Trichopyiton sp. for all concentrations was classified as resistant.

Indeed, there are about 200 Candida fungi species, but only a few species to be a concern because some are dangerous to humans, e.g., C. albicans. The other dangerous species are C. glabrata, C. parapsilosition, $C$. tropicalis, and C. krusei. C. albicans can attack or infect human blood called candidiasis, even causing death. (Molero et al. 1998).

Based on the results of antimicrobial activity evaluation, ethanol extract from agarwood leaves (A. malaccensis Lamk.) showed potential antimicrobial activity against both the test bacteria and the test fungi. For more details, inhibition of zone diameters can be seen in Figure 1. Based on the test, $5 \%$ concentration showed the highest antimicrobial activity of $S$. aureus. On the other side, there was no significant difference between control (Amoxicillin), $20 \%$, and $5 \%$ concentration for the tested fungi. Therefore, it can be assumed that the 5\% concentration already had antimicrobial activity against bacteria and fungi.

\section{The GC-MS analysis}

The phytochemical composition of the ethanol extract from agarwood leaves that had antimicrobial potency was identified using Gas Chromatograph-Mass Spectrometry (GC-MS). The fragmentation pattern of each compound obtained from the spectrogram is shown in Figure 2. The structure of each compound was identified based on the pattern of fragmentation and basic peaks. Table 4 shows the nine compounds identified.

The result shows that the compound of ethanol extracts from agarwood leaves contained phenolic group, on the compound of (E)-1,3-Di-m-tolylallyl ethyl Carbonate, 5-(2Methoxyphenyl)-1,2-dihydropyrazol-3-one, 9-[(tert-Butyldimethylsilyl)oxy]benzo[3,4]cyclod ec-3-ene-1,5-diyne and a-(3-chloro-4-hydroxyphenyl)-aphenoxy-a-phenylacetonitrile. According to Gagola (2004), phenolic compounds have antimicrobial activity. Tannins and flavonoids are compounds that contain phenolic groups. The results of the phytochemical test show that the ethanol extract from agarwood leaves contained flavonoids, tannins, and triterpenoids (Surjanto et al. 2019). Tannins and flavonoids are compounds that contain phenolic groups. Tannin and saponin are antiseptic in surface wounds and work as bacteriostatic; while steroids are anti-inflammatory.

Table 3. Inhibitory zone diameters $(\mathrm{mm})$ of the ethanol extract from agarwood leaves against the tested fungi $C$. albicans and Trichophyton sp.

\begin{tabular}{|c|c|c|}
\hline \multirow{2}{*}{$\begin{array}{c}\text { Concentrations and controls } \\
(\%)\end{array}$} & \multicolumn{2}{|c|}{ Tested fungi } \\
\hline & C. albicans & Trichophyton sp. \\
\hline 20.00 & $16.20 \pm 1.41$ & $6.53 \pm 0.40$ \\
\hline 10.00 & $12.16 \pm 1.85$ & $6.30 \pm 0.40$ \\
\hline 5.00 & $13.90 \pm 0.87$ & $7.36 \pm 0.99$ \\
\hline 2.50 & $11.50 \pm 0.91$ & $6.86 \pm 0.11$ \\
\hline 1.25 & $8.30 \pm 1.72$ & $6.46 \pm 0.15$ \\
\hline Positive control (Amoxicillin) & $6.70 \pm 0.00$ & $6.70 \pm 0.00$ \\
\hline Negative control (Ketonazole) & $0.00 \pm 0.00$ & $0.00 \pm 0.00$ \\
\hline
\end{tabular}

Table 4. Chemical compounds identified of the ethanol extract from agarwood leaves by GC-MS

\begin{tabular}{|c|c|c|c|}
\hline $\begin{array}{l}\text { Retention } \\
\text { time }\end{array}$ & Compound name & $\begin{array}{c}\text { Molecular } \\
\text { formula }\end{array}$ & Biological activity \\
\hline 3.235 & Disulfide, dioctyl & $\mathrm{C}_{16} \mathrm{H}_{34} \mathrm{~S}_{2}$ & Antibacterial (Joondan et al. 2020) \\
\hline 5.858 & 6,7-Dimethylquinoxaline & $\mathrm{C}_{10} \mathrm{H}_{9} \mathrm{FN}_{2}$ & Antimicrobial (El-Gaby et al. 2002) \\
\hline 6.652 & (E)-1,3-Di-m-tolylallyl ethyl carbonate & $\mathrm{C}_{20} \mathrm{H}_{22} \mathrm{O}_{3}$ & Antioxsidant (Paris et al. 2009) \\
\hline 7.687 & 5-(2-Methoxyphenyl)-1,2-dihydropyrazol-3-one & $\mathrm{C}_{10} \mathrm{H}_{10} \mathrm{~N}_{2} \mathrm{O}_{2}$ & Antimicrobial (Obasi et al. 2016) \\
\hline 8.019 & $\begin{array}{l}\text { 9-[(tert-Butyldimethylsilyl)oxy]benzo[3,4]cyclod } \\
\text { ec-3-ene-1,5-diyne }\end{array}$ & $\mathrm{C}_{20} \mathrm{H}_{26} \mathrm{Osi}$ & Antimicrobial (Dunn 2011) \\
\hline 10.106 & Neophytadiene & $\mathrm{C}_{20} \mathrm{H}_{38}$ & $\begin{array}{l}\text { A substance that kills or slows the growth of } \\
\text { microorganisms, including bacteria, viruses, fungi, } \\
\text { and protozoans (Palic et al. 2002; Raman et al. } \\
\text { 2012; Ceyhan-Güvensen and Keskin 2016; Swamy } \\
\text { et al. 2017) }\end{array}$ \\
\hline 10.402 & $\begin{array}{l}\text { 2-Hexadecen-1-ol, 3,7,11,15-tetramethyl-, [R- } \\
{\left[\mathrm{R}^{*}, \mathrm{R}^{*} \text {-(E)]]- }\right.}\end{array}$ & $\mathrm{C}_{20} \mathrm{H}_{40} \mathrm{O}$ & $\begin{array}{l}\text { Diarrhea, anemia, anti-inflammatory, hepatitis, and } \\
\text { anticancer activity (Babu et al. 2014) }\end{array}$ \\
\hline 10.697 & Hexadecanoic acid, methyl ester & $\mathrm{C}_{17} \mathrm{H}_{34} \mathrm{O}_{2}$ & $\begin{array}{l}\text { Antibacterial and antifungal (Chandrasekaran et al. } \\
\text { 2011) }\end{array}$ \\
\hline 13.376 & $\begin{array}{l}\text { a-(3-chloro-4-hydroxyphenyl)-aphenoxy-a- } \\
\text { phenylacetonitrile }\end{array}$ & $\mathrm{C}_{20} \mathrm{H}_{14} \mathrm{ClNO}_{2}$ & Thomas et al. 2013; Yusufov et al. 2020 \\
\hline
\end{tabular}




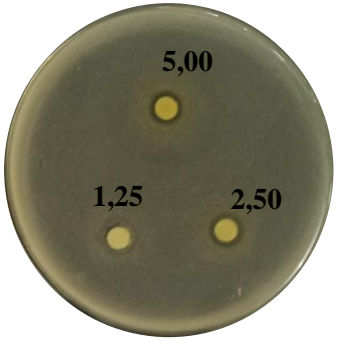

A

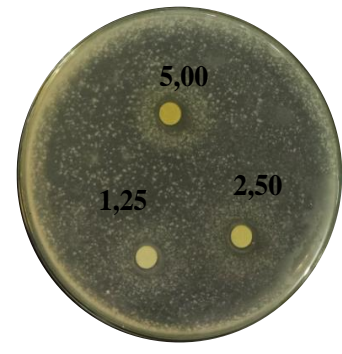

B

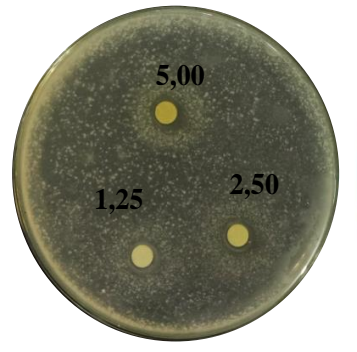

C

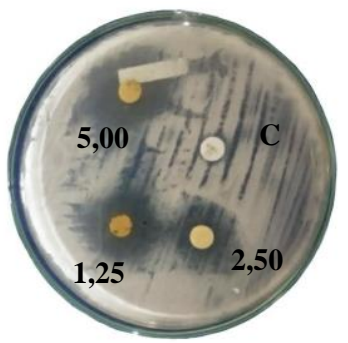

D

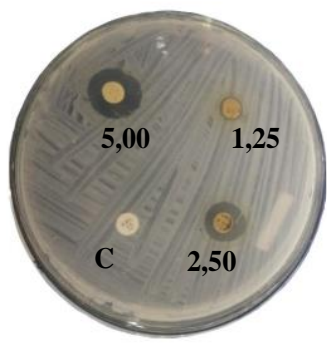

$\mathbf{E}$

Figure 1. Inhibitory zone of the ethanol extract from agarwood leaves on tested fungi and bacteria (C: Control). A. Propionibacterium acnes, B. Staphylococcus epidermidis, C. Trichophyton sp., D. Staphylococcus aureus, E. Candida albicans

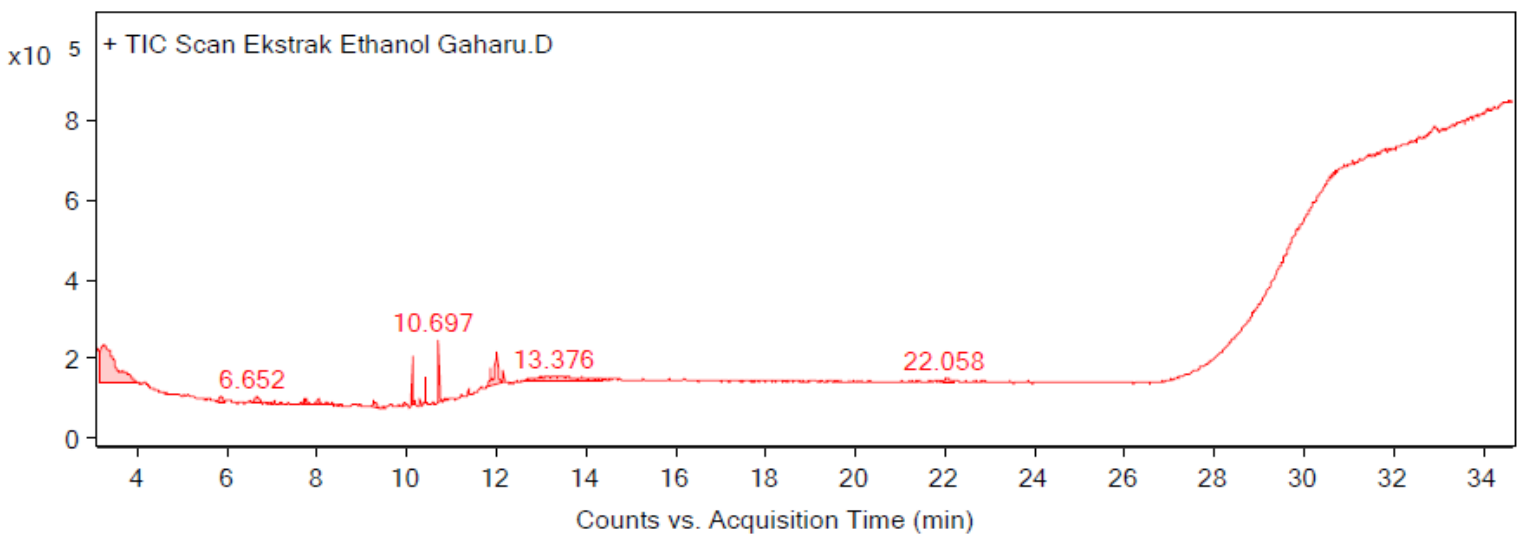

Figure 2. Chromatography of the ethanol extract from agarwood leaves

The biological activity of the chemical compounds contained in the ethanol extract from agarwood leaves can be seen in Table 4, indicating that all compounds identified in the ethanol extract of agarwood leaves have a biological activity based on literature searches. The literature searches show that apart from having antimicrobial properties, the compounds contained in Aquilaria malaccensis Lamk leaves have antioxidant and anti-inflammatory properties as well.

The compounds found in the ethanol extract of agarwood (A. malaccensis) leaves are potential compounds in the pharmaceutical field such as disulfide, neophytadiene, and hexadecanoic acid, methyl ester. Most of the identified compounds on agarwood leaves had biological activity. References show that besides having antimicrobial properties, the compounds found in the ethanol extract of agarwood leaves are potential in the pharmaceutical field, such as disulfide, neophytadiene, hexadecanoic acid, and methyl ester. it is recommended to study further on the ethanol extract from agarwood leaves as the base material for skin disease medicines.

In conclusion, the ethanol extract from agarwood leaves (A. malaccensis) had antibacterial and antifungal activities. The chemical compounds contained in the extract were flavonoids, tannins, and triterpenoids. Identification using GC-MS shows that the ethanol extracts from agarwood leaves had nine biologically active compounds.

\section{ACKNOWLEDGEMENTS}

This research was supported by TALENTA University of Sumatera Utara on the scheme of Penelitian Guru Besar 2019 and by the Ministry of Education and Culture of the Republic of Indonesia for research funding support of the Doctoral Dissertation Program (PDD) in 2020.

\section{REFERENCES}

Adam AZ, Lee SY, Mohamed R. 2017. Pharmacological properties of agarwood tea derived from Aquilaria (Thymelaeaceae) leaves: an emerging contemporary herbal drink. J Herb Med 10: 37-44. DOI: 10.1016/j.hermed.2017.06.002.

Aida AN, Enny S, Misnawi. 2016. In vitro test of the effect of cocoa beans (Theobroma cacao) ethanolic extract as an antibacterial against Propionibacterium acnes. e-Jurnal Pustaka Kesehatan 4 (1): 127-131.

Al-Enazi NM, Awaad AS, Al-Othman MR, Al-Anazi NK, Alqasaumi SI. 2018. Isolation identification and anti-candidal activity of filamentous fungi from Saudi Arabia soil. Saudi Pharm J 26: 253-257. DOI: 10.1016/j.jsps.2017.12.003.

Babu M, Johnson M, Raja DP, Arockiaraj AA, Vinnarasi J. 2014. Chemical constituents and their biological activity of Ulva lactuca Linn. Int J Pharm Drug Anal 2 (7): 595-600.

Batubara R, Hanum TI, Surjanto. 2018. Phytochemical and tannin content in two species of agarwood leaves from Mandailing Natal Regency North Sumatera Province. AIP Conf Proc 2049: 030009-1-030009-5. DOI: $10.1063 / 1.5082510$.

Batubara R, Surjanto, Hanum TI, Handika A, Afandi O. 2020. The screening of phytochemical and antioxidant activity of agarwood leaves (Aquilaria malaccensis) from two sites in North Sumatra, Indonesia. Biodiversitas 21: 1588-1596. DOI: 10.13057/biodiv/d210440. 
Brzuszkiewicz E, Weiner J, Wollherr A, Thürmer A, Hüpeden J, Lomholt HB, Kilian M, Gottschalk G, Daniel R, Mollenkopf H, Meyer TF, Brüggemann H. 2011. Comparative genomics and transcriptomics of Propionibacterium acnes. PLoS One 6 (6): e21581. DOI: 10.1371/journal.pone.0021581

Ceyhan-Güvensen N, Keskin D. 2016. Chemical content and antimicrobial properties of three different extracts of Mentha pulegium leaves from Mugla Regium, Turkey. J Environ Biol 37 : 1341-1346.

Chandrasekaran M, Senthilkumar A, Venkatesalu V. 2011. Antibacterial and antifungal efficacy of fatty acid methyl esters from leaves of Sesuvium portulacastrum L. Eur Rev Med Pharmacol Sci 15 (7): 775-780.

Dewi FK. 2010. Antibacterial activity of noni fruit (Morinda citrifolia Linnaeus) ethanol extract against fresh meat spoilage bacteria. [Thesis]. Universitas Sebelas Maret, Surakarta. [Indonesian]

Diyantika D, Mufida DC, Misnawi. 2017. The morphological changes of Staphylococcus aureus caused by ethanol extracts of Cocoa Beans (Theobroma cacao) through In Vitro. J Agromed Med Sci 1 (1): $25-$ 33. DOI: 10.19184/ams.v3il.4094.

Dunn J. 2011. Synthesis and reactivity of silylmethylcyclopropanes. [Thesis]. University of London. [United Kingdom]

El-Gaby MSA, Ismail MMF, Ammar YA, Zahran MA, Shmeiss NAMM. 2002. Synthesis of novel quinoxaline carboxylic acid derivatives for antimicrobial investigation. Indian J Chem 41B: 1480-1485. DOI: 10.1002/chin.200243193.

Farnsworth NR. 1966. Biological and phytochemical screening of plants. J Pharm Sci 55 (3): 225-276. DOI: 10.1002/jps.260055.

Farizal J, Dewa EARS. 2017. Identification of Candida albican in saliva of woman with diabetes melitus. Jurnal Teknologi Laboratorium 6 (2): 67-74. DOI: 10.29238/teknolabjournal.v6i2.44. [Indonesian]

Fauzi RN, Cahaya, Hidayaturrahmah. 2017. The effect of agarwood (Aquilaria Microcarpa Baill.) leaves ethanol extract addition to bleeding time of histarin-induced white male Wistar rats. J Ilmiah Ibnu Sina 2 (2): 169-175. [Indonesian]

Gagola C. 2004. Antioxidant activity of chalk-white and yellowish flesh cassava (Manihot esculenta) cortex phenolic extract collected from Melonguane city, Talaud Archipelago Regency. J Ilmiah Farmasi Pharmacon 3 (2): 2302-2493. DOI: 10.35799/pha.3.2014.4785.

Gobel BR, Zaraswati D, As`adi A. 2008. General Microbiology in Practice. Universitas Hasanuddin, Makassar. [Indonesian]

Harborne JB. 1987. Phytochemical Methods. Chapman and Hall, London.

Higazy A, Hashem M, ElShafei A, Shaker N, Hady MA. 2010. Development of antimicrobial jute fabrics via in situ formations of cellulose-tannic acid-metal ion complex. Carbohydr Polym 79: 890897. DOI: $10.1016 /$ j.carbpol.2009.10.019.

Ismarani. 2012. The potentials of tannin for supporting environmentally friendly production. CEFARS: Jurnal Agribisnis dan Pengembangan Wilayah 3 (2): 46-55. [Indonesian]

Jansen YR. 2017. Antibacterial activity of gaharu leaves extracts (Aquilaria malaccensis Lamk.) against Pseudomonas aeruginosa and Staphylococcus aureus. Jurnal Universitas Atmajaya, Yogyakarta. [Indonesian]

Joondan N, Inassee MAT, Bhowon MG, Laulloo SJ. 2020. Synthesis and biological properties of a series of aryl alkyl disulfide derivatives. Heliyon 6 (2020): e05368. DOI: 10.1016/j.heliyon.2020.e05368

Kahraman C, Topcu G, Bedir E, Tatli II, Ekizoglu M, Akdemir ZS. 2019 Phytochemical screening and evaluation of the antimicrobial and antioxidant activities of Ferula caspica M. Bieb. extracts. Saudi Pharm J 27: 525-531. DOI: 10.1016/j.jsps.2019.01.016.

Khasanah I, Sarwiyono, Surjowardojo P. 2014. Ethanol extract of muntingia (Muntingia calabura L.) leaves as antibacterial against Streptococcus agalactiae pathogens causing subclinical mastitis in dairy herds. Research Report. Faculty of Animal Science. Universitas Brawijaya, Malang. [Indonesian]

Liana Y. 2017. Antibacterial activity assessment of agarwood plant (Aquilaria malaccensis Lamk.) leaves ethanol extract against Staphylococcus aureus. National Seminar and Workshop Proceedings of Nursery. [Indonesian]

Listiyawati IT, Suyoso S, Rahmadewi. 2017. Profile of fungal and bacterial infections in inguinal erythrosquamous dermatoses. Period Dermatol Venereol 29 (3): 204-211.

Mardiah S. 2008. Antibacterial effectivity of garlic (Allium sativum L.) juice against Staphylococcus aureus growth. Medicra J Med Lab Sci/Technol 1 (2): 44-53.

Miller LG, Eells SJ, Taylor AR, David MZ, Ortiz N, Zychowski D, Kumar N, Cruz D, Boyle-Vavra S, Daum RS. 2012. Staphylococcus aureus colonization among household contacts of patients with skin infections: risk factors, strain discordance, and complex ecology. Clin Infect Dis 54 (11): 1523-1558. DOI: 10.1093/cid/cis213.

Ministry of Health Republic of Indonesia (MoHRI). 2000. Parameter Standar Umum Tumbuhan Obat. MoH RI, Jakarta. [Indonesian]

Molero GRD, Olejas FN, Garcia L, Monteoliva J, Pla C, Gil MS, Perez C, Nombela. 1998. Candida albicans: genetics, dimorphisme phatogenicity. Intl Microbiol 1: 95-106.

Obasi LN, Kaior GU, Rhyman L, Ibrahim, Alswaidan A, Hoong-Kun Fun, Ramasami P. 2016. Synthesis, characterization, antimicrobial screening and computational studies of 4- [3-(4-methoxy-phenyl)allylideneamino]-1,5-dimethyl-2-phenyl-1,2-dihydro-pyrazol-3- one. J Mol Struct 1120: 180-186. DOI: 10.1016/j.molstruc.2016.05.037.

Palic RG, Stojanovic, Alagic S, Nikolic M, Lepojevic Z. 2002. Chemical composition and antimicrobial activity of the essential oil and $\mathrm{CO}_{2}$ extracts of the oriental tobacco, Prilep. Flavour Fragr J 17: 323-326. DOI: $10.1002 /$ ffj. 1048 .

Paris C, Lhiaubet-Vallet V, Jiménez O, Trullas C, Miranda MA. 2009. A blocked dike to form of avobenzone: photostability, photosensitizing, properties and triplet quenching by a triazine-derived UVB-filter. Photochem Photobiol 85: 178-184. DOI: 10.1111/j.17511097.2008.00414.x

Pelczar MJ, Chan ECS. 2008. Dasar-dasar Mikrobiologi 2. UI Press, Jakarta. [Indonesian]

Peng S, Zhao M. 2009. Pharmaceutical bioassay: Methods and applications. John Wiley\& Sons, New Jersey.

Qomar MS, Budiyanto MAK, Sukarsono, Wahyuni S, Husamah. 2018. Effectivity of cinnamon (Cinnamomum burmannii [Ness.] BI) leaves extract at various concentrations for growth inhibitory zone diameter of Staphylococcus epidermidis bacteria. Jurnal Biota 4 (1): 12-18. DOI: 10.19109/Biota.v4i1.1454. [Indonesian]

Radji M. 2011. Buku Ajar Mikrobiologi Panduan Mahasiswa Farmasi dan Kedokteran. EGC, Jakarta. [Indonesian]

Raman BV, Samuel LA, Saradhi MP, Rao BN, Krishna NV, Sudhakar M, Radhakrishnan TM. 2012. Antibacterial, antioxidant activity and GCMS analysis of Eupatorium odoratum. Asian J Pharm Clin Res 5 (2): 99-106

Salawu OA, Aliyu M, Tijani AY. 2008. Haematological studies on the ethanolic stem bark extract of Pterocarpus erinaceus Poir. (Fabaceae). Afr J Biotechnol 7 (9): 1212-1215. DOI: 10.5897/AJB07.393.

Sari R, Muhani M, Fajriaty I. 2017. Antibacterial activity of ethanolic leaves extracts of agarwood (Aquilaria microcarpa Baill.) against Staphylococcus aureus and Proteus mirabilis. Pharm Sci Res 4 (3): 143-154. DOI: 10.7454/psr.v4i3.3756.

Sintowati R, Ambarwati, Kusumawati Y. 2008. Antifungal effectivity of neem (Azadirachta indica) seed against Trichophyton mentagrophytes. Jurnal Kesehatan I (2): 97-102. [Indonesian]

Sudarmadji S, Haryono BS. 2003. Analisa bahan makanan dan pertanian. Liberty, Yogyakarta. [Indonesian]

Surjanto, Batubara R, Hanum TI, Pulungan W. 2019. Phytochemical and antioxidant activity of gaharu leaf tea (Aquilaria malaccensis Lamk) as raw material of tea from middle Tapanuli Regency, North Sumatera Province. IOP Conf Ser: Earth Environ Sci 260: 012101. DOI: $10.1088 / 1755-1315 / 260 / 1 / 012101$.

Swamy MK, Arumugam G, Kaur R, Ghasemzadeh A, Yusoff MM, Sinniah UR. 2017. GC-MS-based metabolite profiling, antioxidant and antimicrobial properties of different solvent extracts of Malaysian Plectranthus amboinicus leaves. Hindawi Evidence-Based Complement Altern Med 2017: 1-10. DOI: 10.1155/2017/1517683.

Tambayong J. 2000. Patofisiologi Untuk Keperawatan. EGC, Jakarta. [Indonesian]

Thomas AB, Nanda RK, Kothapalli LP. 2013. Antimicrobial efficacy of n-[3- chloro-(substituted aryl)-4-oxoazetidin- 1-yl] pyridine-4carboxamides against resistant bacterial strains obtained from clinical isolates. Int Arabic J Antimicrob Agents 3(3). DOI: 10.3823/733.

Wahid AR, Ittiqo DH. 2019. Inhibition activity of agarwood (Aquilaria malea L.) leaves extract as antibacterial agent against Staphylococcus aureus bacteria. Jurnal Insan Farmasi Indonesia 2 (1): 34-43. [Indonesian]

Yusufov MS, Abdushukurov AK, Kholikov TS, Sasmakov SA, Eshboev FB, Abdurakhmanov JM, Azimova SS. 2020. Synthesis of 2-chloron-(3-hydroxyphenyl) acetamide and 2-chloro-n-(4-hydroxyphenyl) acetamide and study of their antimicrobial activity; Proceedings of multidisciplinary international Scientific-practical conference. National University of Uzbekistan, Tashkent, 10-12 December 2020. [Uzbekistan] 